\title{
Characteristics of Tongue Pressures Based on Swallowing Tasks in Korean Healthy Older Adults
}

\author{
Seong Hee Choi ${ }^{1,4}$, HyangHee Kim²,3, Chul-Hee Choi ${ }^{1,4}$, Hae Ni Seo ${ }^{4}$, Chae Rim Park ${ }^{4}$ \\ 'Department of Audiology \& Speech-Language Pathology, Research Institute of Biomimetic Sensory Control, and Catholic Hearing Voice Speech Center, \\ Daegu Catholic University, Gyeongsan, Korea \\ ${ }^{2}$ Graduate Program in Speech and Language Pathology, Yonsei University, Seoul, Korea \\ ${ }^{3}$ Department and Research Institute of Rehabilitation Medicine, Yonsei University College of Medicine, Seoul, Korea \\ ${ }^{4}$ Graduate School of Daegu Catholic University, Daegu, Korea \\ 삼킴 과제에 따른 한국 노년층의 혀압력 특성

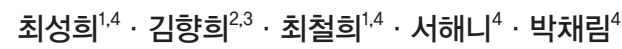 \\ 대구가톨릭대학교 바이오메디대학 언어청각치료학과, 생체모방감각제어연구소, 가톨릭 청각음성언어센터' \\ 연세대학교 의과대학 언어병리학협동과정 ${ }^{2}$, 재활의학교실 및 재활의학연구소 ${ }^{3}$, 대구가톨릭대학교 대학원 언어청각치료학과 ${ }^{4}$
}

To the Editor-in-Chief

We found an error in our published article: Vol. 14, No. 3. 194-203, 2018 / https://doi.org/10.21848/asr.2018.14.3.194

The error of article was a name of funding institution;

This work was supported by the Ministry of Education of the Republic of Korea and National Research Foundation of Korea (NRF-2017M3C1 B6070665).

We would like to convert the funding institution of the above article into corrected one;

This research was supported by the National Research Foundation of Korea (NRF) Grant funded by the Ministry of Science and ICT for convergent research in Development program for convergence R\&D over Science and Technology Liberal Arts (NRF2017M3C1B6070665). 